\title{
Myxobolus arcticus and Parvicapsula minibicornis infections in sockeye salmon Oncorhynchus nerka following downstream migration in British Columbia
}

\author{
A. M. Mahony, S. C. Johnson, C. M. Neville, M. E. Thiess, S. R. M. Jones* \\ Pacific Biological Station, Fisheries and Oceans Canada, Nanaimo, British Columbia V9T 6N7, Canada
}

\begin{abstract}
Factors influencing the health of sockeye salmon Oncorhynchus nerka in British Columbia, Canada, are important for fisheries management and conservation. Juvenile salmon originating from the Fraser River were screened for 3 enzootic parasites (Myxobolus arcticus, Parvicapsula minibicornis, Ceratonova shasta) and the bacterium Renibacterium salmoninarum. Fish were collected from the Strait of Georgia in 2010, 2011 and 2012 and genotyped to stock of origin. Trends in infection status were estimated by year, spawning zone and catch area. The annual prevalences of $P$. minibicornis $(\mathrm{n}=1448)$ were $23.3,6.5$ and $8.1 \%$, and for $M$. arcticus $(\mathrm{n}=1343)$, annual prevalences were $40.4,66.3$ and $27.4 \%$, respectively. Logistic regression showed that $P$. minibicornis was most strongly associated with salmon from the lower Fraser River spawning zone and increased with distance caught from the mouth of the Fraser River. In contrast, infection with $M$. arcticus was most strongly associated with salmon from the middle Fraser River spawning zone, and there was no trend related to distance from the Fraser River. Neither $R$. salmoninarum nor C. shasta were detected. These observations are discussed in the context of salmon life history and pathogen biology.
\end{abstract}

KEY WORDS: Sockeye salmon · Juveniles $\cdot$ Fraser River $\cdot$ Parvicapsula $\cdot$ Myxobolus

\section{INTRODUCTION}

Sockeye salmon Oncorhynchus nerka from the Fraser River in British Columbia (BC), Canada, derive from approximately 90 genetically distinct spawning populations or stocks which for management purposes are divided among 4 run-timing groups (Early Stuart, Early Summer, Summer, Late) defined by their spawning migrations (Beacham et al. 2004). Typically, sockeye rear in freshwater during their first summer, and although 24 nursery lakes are known, approximately $90 \%$ of the production occurs in fewer than 10 lakes (Thomson et al. 2012). For these 'lake-type' stocks, 1 yr old juveniles begin a seaward migration with peak abundance in the

${ }^{*}$ Corresponding author: simon.jones@dfo-mpo.gc.ca lower Fraser River in May, and enter the Strait of Georgia east of Vancouver Island, where they remain resident for 43 to $56 \mathrm{~d}$ (Preikshot et al. 2012, Neville et al. 2016). In contrast, 'sea-type' sockeye salmon, represented in the Fraser River principally by the Harrison River stock, enter the Strait of Georgia in their hatch year approximately 8 wk after the laketype juveniles (Beamish et al. 2016).

The Strait of Georgia has been described as the most important rearing area for juvenile Pacific salmon on Canada's west coast (Beamish et al. 2012). Key to salmon survival in this body of water is the coincidence of the outmigration of juveniles with optimal plankton productivity, which is driven by several oceanographic and meteorological factors

(C) Department of Fisheries and Oceans Canada 2017. Open Access under Creative Commons by Attribution Licence. Use, distribution and reproduction are unrestricted. Authors and original publication must be credited.

Publisher: Inter-Research · www.int-res.com 
(Thomson et al. 2012). By mid-July, most lake-type juvenile sockeye have departed the Strait of Georgia to the northwest into Queen Charlotte Strait and ultimately, to the Gulf of Alaska whence most return to spawn 2 yr later. In contrast, juvenile Harrison River sockeye remain in the Strait of Georgia throughout much of the autumn (Beamish et al. 2016). Generally for given cohorts of Pacific salmon, there is evidence that supports a critical size/critical period hypothesis in which brood year strength is predicted from growth occurring in the first summer at sea: fish that fail to thrive soon after entering the ocean are subject to early-marine mortality due to unknown causes (Beamish \& Mahnken 2001, Farley et al. 2007). Additional mortality during the first winter in the ocean occurs among fish below a critical size that have not accumulated sufficient energy reserves (Beamish \& Mahnken 2001).

The contribution of infection and disease to earlymarine mortality or critical-size-associated mortality among juvenile sockeye salmon is not well understood. Sockeye salmon are exposed to microbes and parasites as juveniles in fresh water, as sub-adults and adults during ocean residence and as mature salmon upon return to fresh water during the spawning migration. Infections are most frequently reported in adult fish captured as part of commercial, recreational or test fisheries either at sea or during the spawning migration. Limited efforts to survey and catalogue the biological characteristics of juvenile sockeye salmon (Preikshot et al. 2012) are reflected in the relatively few reports of infections during early freshwater and marine life history. The objective of this study was to describe spatial and temporal variations in infection with potentially disease-causing microbes and parasites known to be enzootic in sockeye salmon in BC (i.e. Renibacterium salmoninarum, Parvicapsula minibicornis, Myxobolus arcticus and Ceratonova shasta) in an effort to understand the contribution of infectious disease to early marine mortality.

\section{MATERIALS AND METHODS}

\section{Collection and genetic identification of salmon}

Sockeye salmon specimens were collected by purse seine between May and June in 2010, 2011 and 2012 from the Strait of Georgia, Discovery Islands and Johnstone Strait (Fig. 1). An August survey was included only in 2010. Fish included in this study were collected from 182 individual seine sets (29 in

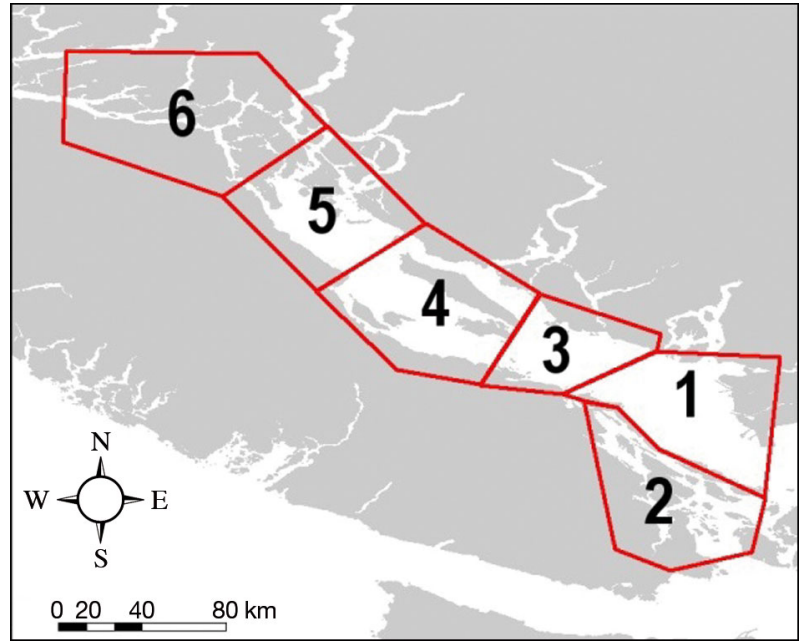

Fig. 1. Boundaries for sockeye salmon Oncorhynchus nerka catch areas in the Strait of Georgia, British Columbia, Canada (see Fig. 2 for location of study area in Western Canada)

2010, 95 in 2011, 58 in 2012) and were killed by immersion in MS222 and frozen whole to $-80^{\circ} \mathrm{C}$ for later dissection. Dissected tissues were stored in liquid nitrogen or in $70 \%$ ethanol until PCR analysis.

Individuals were assigned to stock of origin based on the 2013 sockeye baseline dataset using procedures outlined by Beacham et al. (2014). Individual fish with a probability of assignment less than 0.50 were not included in the analysis.

\section{PCR screening for microbes}

DNA was obtained from the organic-layer of wholebrain Trizol (Thermo Fisher Scientific) extracts by adding $200 \mu \mathrm{l}$ (or $300 \mu \mathrm{l}$ in 2012) of TNES-6U (Tris$\mathrm{HCl}$ pH $7.510 \mathrm{mM}, 125 \mathrm{mM} \mathrm{NaCl}, 10 \mathrm{mM}$ EDTA pH 8.0, $1 \%$ SDS, $6 \mathrm{M}$ urea) and warming to $40^{\circ} \mathrm{C}$. Samples were vigorously shaken, incubated at $20^{\circ} \mathrm{C}$ for $10 \mathrm{~min}$ and centrifuged at $4700 \times g$ for $15 \mathrm{~min}$. The aqueous layer $(\sim 200 \mu \mathrm{l})$ was transferred to a new tube and DNA extracted using a DNeasy blood and tissue kit (Qiagen) as per the manufacturer's instructions. Myxobolus arcticus-specific DNA was amplified following Mahony et al. (2015). Similarly, DNA was extracted from ethanol-preserved intestine or mid-kidney using the DNeasy Tissue kit, described above. Ceratonova shasta-specific DNA was amplified from the intestinal extract following Palenzuela et al. (1999), whereas P. minibicornis- or R. salmoninarum-specific DNA was amplified as described by Kent et al. (2000) or Brown et al. (1994), respectively, from kidney extracts. DNA quality was assessed by 
amplification of small subunit (SSU) rDNA using 18E and 18G primers (Hillis \& Dixon 1991), and controls (tissue-positive and no template) were included in all reactions. PCR products $(8 \mu \mathrm{l})$ were visualized on $1.5 \%$ agarose gels stained with SYBR Safe.

\section{Data partitioning and statistical analysis}

In each year, infection data were analysed according to catch region in the Strait of Georgia and to spawning zone based on stock identity (Figs. $1 \& 2$ ). For descriptive statistics, each sample was assigned to 1 of 6 spawning zones within the Fraser River basin: 1, north central Fraser-Bowron; 2, northern Fraser-Stuart/Stellako; 3, central Fraser-Horsefly; 4, central Fraser-Chilko; 5, mid-Fraser-Thompson/ Shuswap; and 6, lower Fraser (see Fig. 2 for stocks

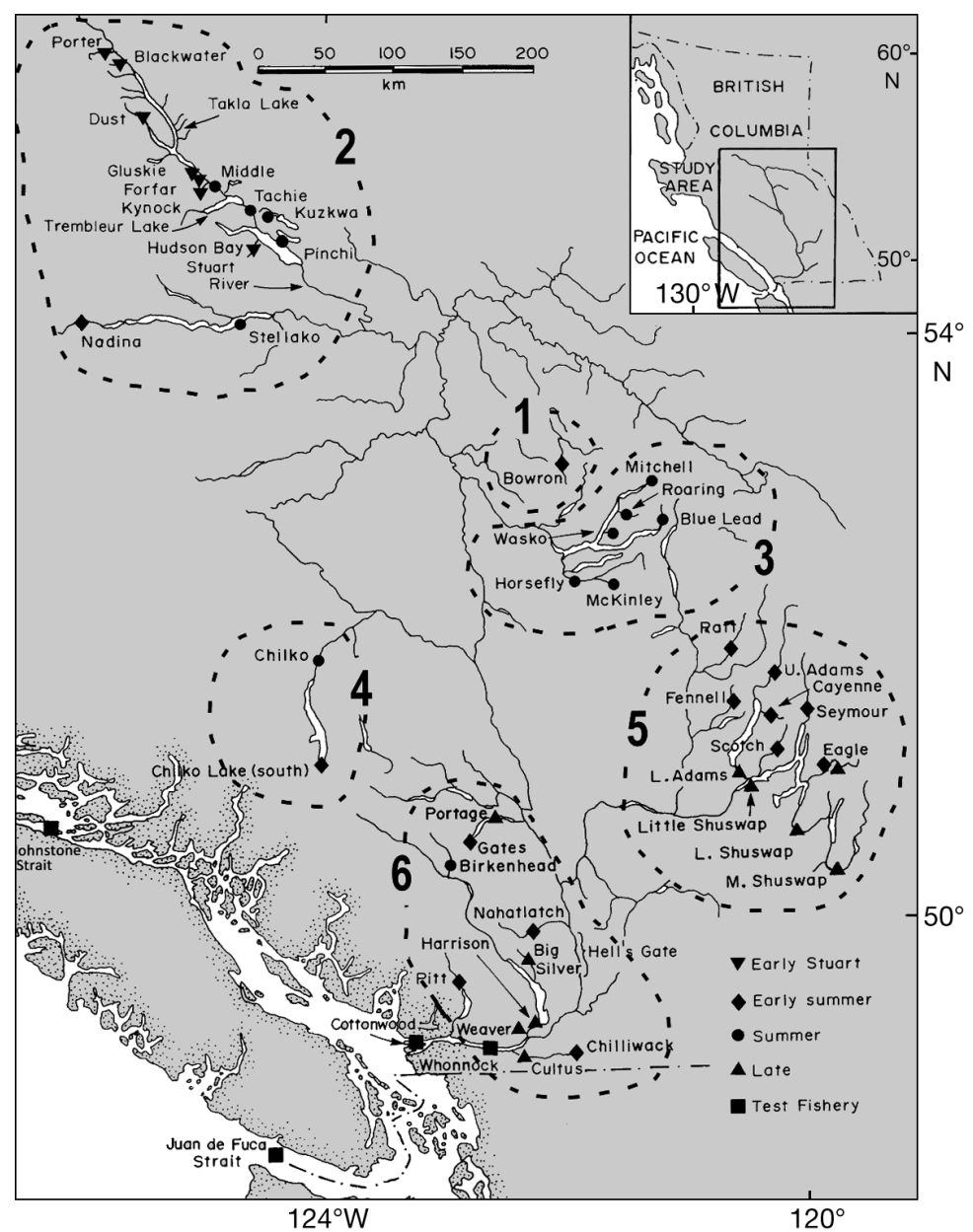

Fig. 2. Spawning zones within the Fraser River basin to which sockeye salmon Oncorhynchus nerka were assigned based on stock of origin. For statistical analyses (see Tables 1-3), zones were aggregated into Northern (1 and 2), Central (3 and 4) and Lower (5 and 6) (see 'Materials and methods') within each spawning zone). Logistic regression analysis (plyr package and glm function in $\mathrm{R}_{i}$ Wickham 2011) was used separately for each microbe or parasite to investigate potential main effects of the explanatory variables year, spawning zone and/or catch region. Significant effects were obtained through iterative runs in which model complexity was sequentially reduced and statistical power in the model was improved by aggregating spawning zones into northern Fraser (zones 1 and 2), central Fraser (zones 3 and 4) and lower Fraser (zones 5 and 6) regions. Results of the logistic regression are presented as odds ratios (ORs), which indicate the risk of infection relative to sockeye salmon caught in 2010, originating from the upper Fraser River spawning zone and caught in the Fraser River plume (catch area 1). Stock-specific infection prevalence was examined for better represented stocks, and chisquared tests were used to test the statistical significance of differences in prevalence across years $(\alpha=0.05)$. Confidence intervals of prevalence for each stock were calculated using the formula:

$$
95 \% \mathrm{CI}= \pm \sqrt{[(p)(1-p) / n]} * Z
$$

where $p=$ mean proportion of positive samples, $Z=1.96$, and $n=$ the total number of samples tested.

\section{RESULTS}

\section{Stock of origin}

A total of 1530 sockeye salmon belonging to 45 stocks were identified in our samples. Five of these stocks (Chilko, Lower Adams, Lower Shuswap, Harrison and Stellako) accounted for $53.5 \%$ of all samples.

\section{Prevalence of infection}

Over 3 years, the prevalence of Parvicapsula minibicornis was $12.4 \%(\mathrm{n}=1448)$ and that of Myxobolus arcticus was $47.8 \%$ ( $\mathrm{n}=$ 1343). The annual mean prevalence (95\% confidence intervals) of $P$. minibicornis was $23.3 \%(19.4-27.1 \%$; $n=473)$ in $2010,6.5 \%$ $(4.5-8.5 \% ; \mathrm{n}=569)$ in 2011 and $8.1 \%$ (5.5-10.8\%; $\mathrm{n}=406)$ in 2012 (Table 1). Similarly, the annual mean prevalence of $M$. arcticus was $40.4 \%(35.0-45.7 \%$; $\mathrm{n}=327)$, 
Table 1. Parvicapsula minibicornis and Myxobolus arcticus in juvenile Fraser River sockeye salmon Oncorhynchus nerka by catch area in the Strait of Georgia and by spawning zone (see Fig. 2 for zone definitions); $n=$ number tested; PCR+: number positive by polymerase chain reaction

\begin{tabular}{|c|c|c|c|c|c|c|c|c|c|c|c|c|c|}
\hline \multirow[t]{3}{*}{ Catch area } & \multirow{3}{*}{$\begin{array}{l}\text { Spawning } \\
\text { zone }\end{array}$} & \multicolumn{6}{|c|}{ _ Parvicapsula minibicornis } & \multicolumn{6}{|c|}{ Myxobolus arcticus } \\
\hline & & \multicolumn{2}{|c|}{2010} & \multicolumn{2}{|c|}{2011} & \multicolumn{2}{|c|}{2012} & \multicolumn{2}{|c|}{2010} & \multicolumn{2}{|c|}{2011} & \multicolumn{2}{|c|}{2012} \\
\hline & & $\mathrm{n}$ & $\mathrm{PCR}+$ & $\mathrm{n}$ & PCR+ & $\mathrm{n}$ & PCR+ & $\mathrm{n}$ & $\mathrm{PCR}+$ & $\mathrm{n}$ & PCR+ & $\mathrm{n}$ & PCR+ \\
\hline \multirow[t]{3}{*}{ 1-Fraser Plume } & Northern & 1 & 0 & 20 & 0 & 2 & 0 & 0 & 0 & 20 & 0 & 1 & 0 \\
\hline & Central & 2 & 0 & 57 & 1 & 9 & 2 & 2 & 2 & 57 & 50 & 9 & 8 \\
\hline & Lower & 48 & 21 & 18 & 0 & 65 & 0 & 3 & 1 & 18 & 4 & 65 & 0 \\
\hline \multirow[t]{3}{*}{ 2-Gulf Islands } & Northern & 0 & 0 & 1 & 0 & 0 & 0 & 0 & 0 & 3 & 1 & 0 & 0 \\
\hline & Central & 0 & 0 & 55 & 1 & 11 & 1 & 0 & 0 & 67 & 63 & 11 & 10 \\
\hline & Lower & 0 & 0 & 4 & 2 & 45 & 2 & 0 & 0 & 12 & 5 & 45 & 6 \\
\hline \multirow[t]{3}{*}{ 3-Middle/Lower } & Northern & 0 & 0 & 10 & 1 & 0 & 0 & 0 & 0 & 12 & 3 & 0 & 0 \\
\hline & Central & 0 & 0 & 46 & 0 & 13 & 0 & 0 & 0 & 51 & 43 & 15 & 14 \\
\hline & Lower & 2 & 2 & 25 & 5 & 62 & 3 & 0 & 0 & 28 & 8 & 68 & 8 \\
\hline \multirow[t]{3}{*}{ 4-Middle/Upper } & Northern & 16 & 1 & 23 & 0 & 9 & 2 & 16 & 2 & 23 & 4 & 9 & 6 \\
\hline & Central & 29 & 4 & 60 & 1 & 26 & 2 & 29 & 20 & 60 & 57 & 26 & 21 \\
\hline & Lower & 22 & 1 & 32 & 3 & 69 & 7 & 22 & 7 & 32 & 11 & 73 & 9 \\
\hline \multirow[t]{3}{*}{ 5-Upper } & Northern & 63 & 6 & 15 & 1 & 22 & 0 & 47 & 5 & 15 & 5 & 22 & 7 \\
\hline & Central & 75 & 12 & 66 & 6 & 17 & 2 & 51 & 47 & 64 & 57 & 18 & 13 \\
\hline & Lower & 62 & 12 & 24 & 9 & 56 & 12 & 49 & 11 & 21 & 7 & 57 & 13 \\
\hline \multirow[t]{3}{*}{ 6-Lower Johnstone Strait } & Northern & 49 & 17 & 14 & 2 & 0 & 0 & 38 & 3 & 14 & 2 & 0 & 0 \\
\hline & Central & 49 & 14 & 81 & 2 & 0 & 0 & 30 & 24 & 81 & 73 & 0 & 0 \\
\hline & Lower & 55 & 20 & 18 & 7 & 0 & 0 & 40 & 10 & 18 & 2 & 1 & 0 \\
\hline
\end{tabular}

$66.3 \%(62.5-70.1 \% ; \mathrm{n}=596)$ and $27.4 \%(23.1-$ $31.6 \% ; \mathrm{n}=420 ;$ Table 1). Neither Renibacterium salmoninarum nor Ceratonova shasta were detected in any of 1744 or 1761 samples, respectively.

The mean prevalence of $M$. arcticus and $P$. minibicornis across catch areas and by spawning zone for each of 2010, 2011 and 2012 is illustrated in Fig. 3. For each parasite, logistic regression was used to estimate the significance of year, catch area and spawning zone as a predictor of risk of infection. For both parasites, OR is expressed relative to year = 2010, spawning zone $=$ Northern Fraser and catch area $=1$ (Fraser River plume). These analyses showed that the risk of $M$. arcticus was significantly higher in $2011(\mathrm{OR}=1.84)$ and among salmon spawning in the Central Fraser zone (OR $=34.00$; Table 2). Similarly, the risk of infection was significantly elevated among salmon caught in catch areas 2,4 and 5 (Table 2). For $P$. minibicornis, the risk of infection was significantly less (OR $=0.38$ and 0.33 ) in 2011 and 2012, respectively (Table 2) and was significantly greater $(\mathrm{OR}=2.6)$ for salmon spawning in the Lower Fraser zone. Likewise, the risk of infection was significantly greater $(\mathrm{OR}=2.6)$ for fish caught in the lower Johnstone Strait (Catch Area 6).

When all years were combined, the prevalence of $M$. arcticus varied significantly $\left(\chi^{2}=382.0, p<0.001\right)$ among the Chilko, Lower Shuswap, Lower Adams and Stellako salmon stocks. There was significant variation in the prevalence of $P$. minibicornis among stocks when Harrison stock salmon were included $\left(\chi^{2}\right.$ $=73.4, \mathrm{p}<0.001)$, but not when they were excluded $\left(\chi^{2}=4.2, \mathrm{p}=0.123\right)$. A prevalence of $45 \%$ for $P$. minibicornis in Harrison River sockeye from the August 2010 survey was the highest observed for this parasite in this study. In this survey, the fish were collected in catch areas 1 (18 of 37 positive) and 3 ( 1 of 1 positive). Infected Harrison sockeye were also collected during surveys in May (1 of 1 infected in catch area 4 ) and June (2 of 8 infected in catch area 1; 1 of 4 infected in catch area 6). The extent of annual variability in parasite prevalence was species specific (Table 3). In Chilko salmon, the annual prevalence of M. arcticus was relatively high and moderately variable: $83.8 \%(76.5-91.1 \%), 91.1 \%(87.4-94.6 \%)$ and $78.4 \%\left(65.1-91.7 \% ; \chi^{2}=7.0, p=0.03\right)$, respectively while that of $P$. minibicornis was relatively low and highly variable: $20.1 \%(13.3-26.9 \%), 2.5 \% \quad(0.5-$ $4.5 \%)$ and $8.6 \%\left(0-17.9 \% ; \chi^{2}=32.7, \mathrm{p}<0.001\right)$, respectively.

\section{DISCUSSION}

This study confirmed that infections with Мyхоbolus arcticus and Parvicapsula minibicornis occur among juvenile sockeye salmon following their migration from the Fraser River and provided insight into spatial and temporal variations in the overall and stock-specific prevalence. $M$. arcticus is a parasite of 

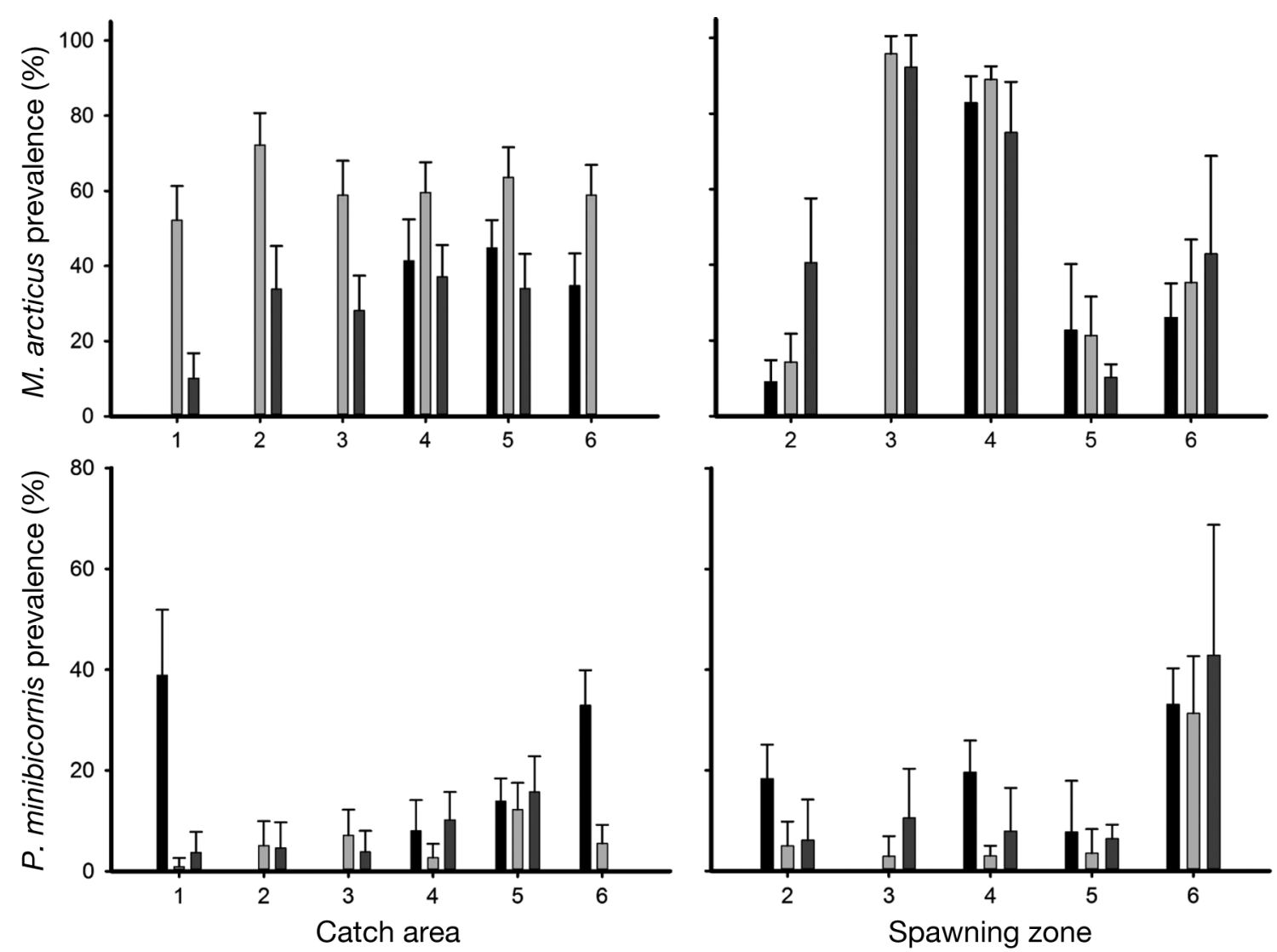

Fig. 3. Mean prevalence (error bars are $95 \%$ confidence intervals) of Myxobolus arcticus and Parvicapsula minibicornis in juvenile Fraser River sockeye salmon Oncorhynchus nerka by catch area and spawning zone (see 'Materials and methods') in 2010 (black), 2011 (light gray) and 2012 (dark gray). For any year, prevalence was not calculated when $\mathrm{n}<10$ (missing bars). In no year was $\mathrm{n} \geq 10$ for either parasite in spawning zone 1

the anterior spinal cord or hindbrain of sockeye salmon that elicits negligible overt pathology. Our finding of $M$. arcticus in 27 to $66 \%$ of juvenile Fraser River sockeye collected from the Strait of Georgia over 3 yr was consistent with Mahony et al. (2015), who reported the parasite in 53 and $71 \%$ of histological brain preparations from juvenile sockeye salmon collected at the Chilko Lake smolt fence in 2010 and 2011, respectively. Nearly all (96\%) of the latter group were found to be infected by using PCR (Mahony et al. 2015). There was no evidence in the present study for trends in the prevalence of $M$. arcticus among catch areas in the Strait of Georgia during the $6-8$ wk residency of juvenile sockeye within the Strait of Georgia. The prevalence would be expected to drop if infected fish were preferentially removed, as shown for poor-condition juvenile salmon under avian predation pressure (Tucker et al. 2016). This may indicate that the infections in Fraser River sockeye were not as severe as those in the Alaskan sockeye associated with reduced swimming speed (Moles \& Heifetz 1998).
The wide distribution of $M$. arcticus, combined with its spatial heterogeneity and apparent stability over time (Moles \& Heifetz 1998, Moles \& Jensen 2000) has in the past supported use of this parasite, then referred to as $M$. neurobius, as a biological tag to aid in the discrimination of sockeye salmon stocks in the Pacific Northwest of North America (Bailey \& Margolis 1987, Quinn et al. 1987). The variable prevalence of $M$. arcticus among salmon populations is related to conditions in salmon natal lakes that are suitable for the annelid intermediate host Stylodrilus heringianus (Kent et al. 1993, Moles \& Jensen 2000). Not surprisingly, our analyses showed statistically significant variation in prevalence among salmon stocks and that salmon from the central Fraser spawning zone (Quesnel, Chilko and Thompson River drainages) were 34 times more likely to be infected than those from the lower Fraser zone (Pitt, Harrison and Chilliwack Rivers). This is consistent with Bailey \& Margolis (1987), who reported the parasite in 62.0 and $66.0 \%$ of smolts from Quesnel and Bowron Lakes, respectively. Interestingly, unlike 
Table 2. Logistic regression analysis of main effects (Year, Geographic Spawning Zone, Run Timing and Catch Area) related to prevalence of infection with Myxobolus arcticus or Parvicapsula minibicornis in juvenile Fraser River sockeye salmon Oncorhynchus nerka. OR: odds ratio; Intercept: fish caught in 2010 from the Northern Fraser River geographic spawning zone, and caught in the Fraser River plume catch area. Bold values: significant

\begin{tabular}{|c|c|c|c|}
\hline & OR & $\mathrm{CI}$ & $\mathrm{p}$ \\
\hline \multicolumn{4}{|l|}{ M. arcticus } \\
\hline (Intercept) & 0.07 & $0.04-0.14$ & $<0.001$ \\
\hline \multicolumn{4}{|l|}{ Year } \\
\hline 2011 & 1.84 & $1.22-2.78$ & $\mathbf{0 . 0 0 4}$ \\
\hline 2012 & 0.84 & $0.53-1.33$ & 0.456 \\
\hline \multicolumn{4}{|l|}{ Geographic Spawning Zone } \\
\hline Central Fraser & 34.04 & $22.02-53.85$ & $<<0.001$ \\
\hline Lower Fraser & 1.33 & $0.86-2.07$ & 0.205 \\
\hline \multicolumn{4}{|l|}{ Catch Area } \\
\hline 2-Gulf Islands & 2.79 & $1.44-5.45$ & 0.002 \\
\hline 3-Middle Strait of Georgia & 1.83 & $1.00-3.38$ & 0.051 \\
\hline $\begin{array}{l}\text { 4-Upper/Middle Strait of } \\
\text { Georgia }\end{array}$ & 2.39 & $1.39-4.17$ & 0.002 \\
\hline 5-Upper Strait of Georgia & 2.84 & $1.63-5.01$ & $<0.001$ \\
\hline 6-Lower Johnstone Strait & 1.74 & $0.95-3.22$ & 0.074 \\
\hline Observations & 132 & & \\
\hline \multicolumn{4}{|l|}{ P. minibicornis } \\
\hline (Intercept) & 0.13 & $0.07-0.23$ & $<0.001$ \\
\hline \multicolumn{4}{|l|}{ Year } \\
\hline 2011 & 0.38 & $0.25-0.58$ & $<0.001$ \\
\hline 2012 & 0.33 & $0.20-0.54$ & $<0.001$ \\
\hline \multicolumn{4}{|l|}{ Geographic Spawning Zone } \\
\hline Central Fraser & 0.91 & $0.55-1.53$ & 0.726 \\
\hline Lower Fraser & 2.56 & $1.61-4.16$ & $<0.001$ \\
\hline \multicolumn{4}{|l|}{ Catch Area } \\
\hline 2-Gulf Islands & 0.78 & $0.27-1.92$ & 0.608 \\
\hline 3-Middle Strait of Georgia & 0.90 & $0.40-1.91$ & 0.787 \\
\hline $\begin{array}{l}\text { 4-Upper/Middle Strait of } \\
\text { Georgia }\end{array}$ & 0.81 & $0.43-1.53$ & 0.522 \\
\hline 5-Upper Strait of Georgia & 1.50 & $0.89-2.60$ & 0.139 \\
\hline 6-Lower Johnstone Strait & 2.56 & $1.48-4.55$ & 0.001 \\
\hline Observations & 136 & & \\
\hline
\end{tabular}

here or in Mahony et al. (2015), Bailey \& Margolis (1987) found no evidence of the parasite in 244 juvenile sockeye sampled from Chilko Lake between 1976 and 1982. Evidently, the distribution of the par- asite among natal lakes is not stable over decadal time scales. The mechanisms of parasite introduction into previously naïve populations are not known but may be related to infected salmon straying among natal lakes (Quinn et al. 1987) or to vector-mediated movement of infected annelid or fish hosts among lakes (Moles \& Jensen 2000).

$P$. minibicornis was originally described from spawning sockeye salmon in the Fraser River (Kent et al. 1997) where it also occurs in coho Oncorhynchus kisutch and pink salmon O. gorbuscha (Jones et al. 2003). In the adult sockeye, severe infection is associated with pathological changes in affected glomeruli and renal tubules (Raverty et al. 2000). The parasite has also been reported from adult Pacific salmon in the Columbia and Klamath Rivers (Jones et al. 2004, Bartholomew et al. 2007, Atkinson et al. 2011). Our detection of $P$. minibicornis confirms an earlier study in which the parasite was reported in juvenile Fraser River sockeye salmon in the Strait of Georgia. St-Hilaire et al. (2002) used PCR to demonstrate the infection in approximately $60 \%$ of 67 juveniles collected from an unreported location in the lower Strait of Georgia. P. minibicornis was reported in juvenile Chinook salmon $O$. tshawytscha in the Klamath River, California, USA (Foott et al. 2004), where infective actinospores are shed by the polychaete host, Manayunkia sp. (Bartholomew et al. 2006). In the present study, the risk of infection with P. minibicornis was significantly reduced in 2011 and 2012, a pattern strongly influenced by the elevated prevalence in juvenile sockeye from the Fraser River plume and the lower Johnstone Strait/western Discovery Islands in 2010. In 2010, most infected salmon were collected in August, and these belonged to the Harrison River stock. Harrison River sockeye display a sea-type behaviour in which they spend their first spring and summer in the lower Fraser River before migrating to the ocean, a behaviour which evidently increases their risk of exposure to the parasite (StHilaire et al. 2002).

Table 3. Occurrence of Myxobolus arcticus and Parvicapsula minibicornis among 5 Fraser River sockeye salmon Oncorhynchus nerka stocks from 2010 to $2012 ; \mathrm{n}=$ number tested; \% : percent positive by PCR

\begin{tabular}{|c|c|c|c|c|c|c|c|c|c|c|c|c|}
\hline \multirow[t]{3}{*}{ Stock } & \multirow{2}{*}{\multicolumn{4}{|c|}{$\begin{array}{c} \\
2010\end{array}$}} & \multirow{2}{*}{\multicolumn{2}{|c|}{2012}} & \multirow{2}{*}{\multicolumn{2}{|c|}{$\overline{2010} P_{c}$}} & \multicolumn{3}{|c|}{ - Parvicapsula minibicornis } & \\
\hline & & & & & & & & & & & & \\
\hline & $\mathrm{n}$ & $\%$ & $\mathrm{n}$ & $\%$ & $\mathrm{n}$ & $\%$ & $\mathrm{n}$ & $\%$ & $\mathrm{n}$ & $\%$ & $\mathrm{n}$ & $\%$ \\
\hline Chilko & 99 & 83.8 & 246 & 91.0 & 37 & 78.4 & 134 & 20.1 & 236 & 2.5 & 35 & 8.6 \\
\hline Shuswap & 0 & 0 & 0 & 0 & 100 & 11.0 & 0 & 0 & 0 & 0 & 94 & 4.3 \\
\hline Adams & 0 & 0 & 21 & 19.0 & 109 & 9.2 & 1 & 100.0 & 20 & 0.0 & 105 & 6.7 \\
\hline Stellako & 46 & 8.7 & 8 & 50.0 & 24 & 37.5 & 60 & 15.0 & 7 & 0.0 & 24 & 4.2 \\
\hline Harrison & 4 & 25.0 & 0 & 0 & 0 & 0 & 51 & 45.1 & 0 & 0 & 0 & 0 \\
\hline
\end{tabular}


Epidemiological evidence indicates transmission of $P$. minibicornis to salmon as they migrate through the lower Fraser River. In adult salmon, prevalence and severity progressively increase with distance migrated in the river (St-Hilaire et al. 2002, Jones et al. 2003). In the present study and with the exception of the aforementioned 2010 catches, there was a trend of increasing prevalence in juvenile salmon with distance from the Fraser River plume, and this was statistically significant for the Lower Johnstone Strait. This pattern of increasing prevalence and severity, whether in spawning adult salmon or in oceanmigrating juveniles, may be explained by the proliferative development of the parasite following transmission. In adult salmon, the most severe infections coincide with post-spawning mortality (Raverty et al. 2000, Jones et al. 2003), and more severe pathological consequences occur when the spawning migration is delayed in-river (Cooke et al. 2004) or when water temperatures increase during the in-river migration (Wagner et al. 2005, Crossin et al. 2008). The outcome of the infection in juveniles is not known, but the infections are not detectable in returning adults until they re-enter the river on the spawning migration (Jones et al. 2003). In this context, Miller et al. (2014) found quantitative PCR evidence for $P$. minibicornis in juvenile sockeye salmon from Queen Charlotte Sound, approximately $100 \mathrm{~km}$ WNW of catch area 6 . In that study, the parasite occurred at a higher prevalence $(46 \%)$ in fish that had been predated by rhinoceros auklets Cerorhinca monocerata compared with a reference population (24\% prevalence).

Ceratonova shasta is a parasite of the intestinal epithelium of Pacific salmon that occurs among coastal rivers and their tributaries in northern California, Oregon, Washington, Idaho, BC and Alaska (Follett et al. 1994, Bartholomew et al. 1997). In the American rivers studied, salmon are infected in freshwater by exposure to waterborne actinospores which are shed from the polychaete host Manayunkia sp. (Bartholomew et al. 1997). Infection with the parasite causes ceratomyxosis, which presents as a severe enteritis or in later stages as a systemic infection. The severity of ceratomyxosis is host-specific and increases with water temperature (Bartholomew 1998, Foott et al. 2004). In the Fraser River drainage basin, the parasite occurs in Chinook salmon, coho salmon, pink salmon, rainbow trout O. mykiss and cutthroat trout O. clarkii (McDonald 1983, Bell \& Traxler 1985). Failure to detect C. shasta in juvenile Fraser River sockeye salmon in the present study may have been related to an apparently lower sus- ceptibility of sockeye salmon (Zinn et al. 1977) or to the early timing of smolt outmigration relative to the spring increase in infectivity of river water (Ching \& Munday 1984). Margolis et al. (1992) suggested the relatively low prevalence (3.3-9.1\%) of C. shasta in Chinook salmon smolts examined over $3 \mathrm{yr}$ in the Fraser River was related to most salmon having left the river before the period of elevated infectivity in mid-May. The mean date of sockeye smolt migration in the Fraser River from late April to mid-May (Preikshot et al. 2012, Neville et al. 2016) suggests that migration in this species also preceded the infectious period.

Renibacterium salmoninarum is a Gram-positive diplobacillus and the causative agent of bacterial kidney disease (BKD), a chronic condition causing morbidity and mortality in cultured salmonid fishes in many parts of the world (Evelyn 1993). In western North America, infections are widespread among Pacific salmon in fresh water and in the ocean (Banner et al. 1986, Meyers et al. 1993, Kent et al. 1998) and also in cultured salmon (Evelyn 1993). The bacterium has frequently been detected in juvenile Pacific salmon in fresh and coastal waters of the western USA (Sanders et al. 1992, Arkoosh et al. 2004, Van Gaest et al. 2011, Sandell et al. 2015). The mean prevalence of $R$. salmoninarum in juvenile Chinook salmon from 12 coastal locations ranged from 10 to $68 \%$ (Arkoosh et al. 2004). At Alsea Bay, annual prevalence over 6 yr ranged from 0 to $44 \%$ (Arkoosh et al. 2004). Infection with $R$. salmoninarum has repeatedly been diagnosed in adult sockeye salmon returning to the Fraser River. The prevalence in adult Cultus Lake sockeye between 2002 and 2015 ranged from $0.6 \%$ (n = 160) to $89.1 \%(n=101)$ (Department of Fisheries and Oceans Canada [DFO] unpublished data). Similarly, the prevalence of infections in adult sockeye salmon from other Fraser River sites was $75 \%$ at Weaver Creek in 2010 ( $\mathrm{n}=20), 1.7-56.1 \%$ at Inch Creek between 2011 and 2014 ( $\mathrm{n}=54-139$ ) and 2.9-7.5\% at Henderson Lake between 1996 and 1998 ( $\mathrm{n}=$ 35-63; DFO unpublished). Thus R. salmoninarum was absent in juvenile sockeye salmon in the present study despite evidence for its widespread occurrence in spawning Fraser River sockeye salmon, the susceptibility of sockeye salmon to the infection and to BKD (Sanders et al. 1978, Bell et al. 1984) and despite the tendency for the bacterium to be vertically transmitted within the ovum (Evelyn et al. 1984). Our inability to detect $R$. salmoninarum may have been related to sample sizes that were too small, to low-level infections that occurred below 
the limit of detection or to the loss from the population of infected juveniles prior to migration to the ocean. In the present study, we did not screen juvenile sockeye for $R$. salmoninarum during their period of freshwater residence, and this knowledge gap should be remedied by focussing on the epidemiology and outcome of infections in juvenile sockeye salmon in fresh and marine waters.

In conclusion, this study furthers our understanding of parasite dynamics in juvenile sockeye salmon belonging to a complex mix of genetic stocks migrating from the Fraser River drainage basin. Foci of transmission of myxosporean parasites are related to the distribution and abundance of the invertebrate host. In migratory species like anadromous salmon, duration of residence within waters occupied by the invertebrate host increases the risk of infection. The observed patterns of infection supported the hypothesis that some natal systems within the drainage basin are more conducive than others to the transmission of $M$. arcticus. In addition, prolonged residency of Harrison River stock sockeye salmon in the lower Fraser River is consistent with increased risk of $P$. minibicornis infection. Data supporting the impacts of these infections on salmon survival were less clear. The prevalence of $M$. arcticus and $P$. minibicornis either remained constant or increased following salmon migration to the ocean, neither result supporting a hypothesis of infection-induced early marine mortality. In contrast, the possibility of lethal infections with $C$. shasta and $R$. salmoninarum resulting in their absence from populations sampled in the present study reinforced a need for improved surveillance in juvenile sockeye during their period of freshwater residency.

Acknowledgements. We thank J. Bradshaw and G. Prosperi-Porta for assistance with sample preparation and PCR. Thanks also to J. Bradshaw, Y. Jung, D. Conover and numerous volunteers and technicians, along with the captains and crews of the CFV 'Nordic Queen' and CFV 'Ocean Venture' for assistance with sample collections. Funding was provided by the DFO's Program for Aquaculture Regulatory Research.

\section{LITERATURE CITED}

Arkoosh MR, Clemons E, Kagley AN, Stafford C and others (2004) Survey of pathogens in juvenile salmon Oncorhynchus spp. migrating through Pacific Northwest estuaries. J Aquat Anim Health 16:186-196

Atkinson SD, Jones SRM, Adlard RD, Bartholomew JL (2011) Geographical and host distribution patterns of Parvicapsula minibicornis (Myxozoa) small subunit ribosomal RNA genetic types. Parasitology 138:969-977
Bailey RE, Margolis L (1987) Comparison of parasite fauna of juvenile sockeye salmon (Oncorhynchus nerka) from southern British Columbian and Washington State lakes. Can J Zool 65:420-431

*Banner CR, Long JJ, Fryer JL, Rohovec JS (1986) Occurrence of salmonid fish infected with Renibacterium salmoninarum in the Pacific Ocean. J Fish Dis 9:273-275

* Bartholomew JL (1998) Host resistance to infection by the myxosporean parasite Ceratomyxa shasta: a review. J Aquat Anim Health 10:112-120

Bartholomew JL, Whipple MJ, Stevens DG, Fryer JL (1997) The life cycle of Ceratomyxa shasta, a myxosporean parasite of salmonids, requires a freshwater polychaete as an alternate host. J Parasitol 83:859-868

* Bartholomew JL, Atkinson SD, Hallett SL (2006) Involvement of Manayunikia speciosa (Annelida: Polychaeta: Sabellidae) in the lifecycle of Parvicapsula minibicornis, a myxozoan parasite of Pacific salmon. J Parasitol 92: 742-748

* Bartholomew JL, Atkinson SD, Hallett SL, Zielinski CM, Foott JS (2007) Distribution and abundance of the salmonid parasite Parvicapsula minibicornis (Myxozoa) in the Klamath River basin (Oregon-California, USA). Dis Aquat Org 78:137-146

Beacham TD, Lapointe M, Candy JR, McIntosh B and others (2004) Stock identification of Fraser River sockeye salmon using microsatellites and major histocompatibility complex variation. Trans Am Fish Soc 133:1117-1137

* Beacham TD, Beamish RJ, Candy JR, Wallace C, Tucker S, Moss JH, Trudel M (2014) Stock-specific size of juvenile sockeye salmon in British Columbia waters and the Gulf of Alaska. Trans Am Fish Soc 143:876-889

*Beamish RJ, Mahnken C (2001) A critical size and period hypothesis to explain natural regulation of salmon abundance and the linkage to climate and climate change. Prog Oceanogr 49:423-437

Beamish RJ, Neville C, Sweeting R, Lange K (2012) The synchronous failure of juvenile Pacific salmon and herring production in the Strait of Georgia in 2007 and the poor return of sockeye salmon to the Fraser River in 2009. Mar Coast Fish 4:403-414

* Beamish RJ, Neville CM, Sweeting RM, Beacham TD, Wade J, Li L (2016) Early ocean life history of Harrison River sockeye salmon and their contribution to the biodiversity of sockeye salmon in the Fraser River, British Columbia, Canada. Trans Am Fish Soc 145:348-362

* Bell GR, Traxler G (1985) First record of viral erythrocytic necrosis and Ceratomyxa shasta Noble, 1950 (Myxozoa: Myxosporea) in feral pink salmon (Oncorhynchus gorbuscha Walbaum). J Wildl Dis 21:169-171

* Bell GR, Higgs DA, Traxler GS (1984) The effect of dietary ascorbate, zinc, and manganese on the development of experimentally induced bacterial kidney disease in sockeye salmon (Oncorhynchus nerka). Aquaculture 36: 293-311

*Bown LL, Iwama GK, Evelyn TPT, Nelson WS, Levine RP (1994) Use of the polymerase chain reaction (PCR) to detect DNA from Renibacterium salmoninarum within individual salmonid eggs. Dis Aquat Org 18:165-171

* Ching HL, Munday DR (1984) Geographic and seasonal distribution of the infectious stage of Ceratomyxa shasta Noble, 1950, a myxozoan salmonid pathogen in the Fraser River system. Can J Zool 62:1075-1080

* Cooke SJ, Hinch SG, Farrell AP, Lapointe MF and others (2004) Abnormal migration timing and high en route 
mortality of sockeye salmon in the Fraser River, British Columbia. Fisheries 29:22-33

Crossin GT, Hinch SG, Cooke SJ, Welch DW and others (2008) Exposure to high temperature influences the behaviour, physiology, and survival of sockeye salmon during spawning migration. Can J Zool 86:127-140

Evelyn TPT (1993) Bacterial Kidney Disease - BKD. In: Inglis V, Roberts RJ, Bromage NR (eds) Bacterial diseases of fish. Blackwell Scientific Publications, Oxford, p 177-195

Evelyn TPT, Ketcheson J, Prosperi-Porta G (1984) Further evidence for the presence of Renibacterium salmoninarum in salmonid eggs and for the failure of povidoneiodine to reduce the intra-ovum infection rate in waterhardened eggs. J Fish Dis 7:173-182

Farley EV Jr, Moss JH, Beamish RJ (2007) A review of the critical size, critical period hypothesis for juvenile Pacific salmon. North Pac Anadromous Fish Comm Bull 4: 311-317

Follett JE, Geesin JL, Burton TM (1994) Detection of Ceratomyxa shasta in Alaska chum salmon, Oncorhynchus keta. Alsk Fish Res Bull 1:97-98

Foott J, Harmon R, Stone R (2004) Effect of water temperature on non-specific immune function and ceratomyxosis in juvenile Chinook salmon and steelhead from the Klamath River. Calif Fish Game 90:71-84

Hillis DM, Dixon MT (1991) Ribosomal DNA: molecular evolution and phylogenetic inference. Q Rev Biol 66: 411-453

Jones SRM, Prosperi-Porta G, Dawe SC, Barnes DP (2003) Distribution, prevalence and severity of Parvicapsula minibicornis infections among anadromous salmonids in the Fraser River, British Columbia, Canada. Dis Aquat Org 54:49-54

Jones SRM, Prosperi-Porta G, Dawe S, Taylor K, Goh B (2004) Parvicapsula minibicornis in anadromous sockeye (Oncorhynchus nerka) and coho (Oncorhynchus kisutch) salmon from tributaries of the Columbia River. J Parasitol 90:882-885

Kent ML, Whitaker DJ, Margolis L (1993) Transmission of Myxobolus arcticus Pugachev and Khokhlov, 1979, a myxosporean parasite of Pacific salmon, via a trictinomyxon from the aquatic oligochaete Stylodrilus heringianus (Lumbriculidae). Can J Zool 71:1207-1211

Kent ML, Whitaker DJ, Dawe SC (1997) Parvicapsula minibicornis n. sp. (Myxozoa, Myxosporea) from the kidney of sockeye salmon (Oncorhynchus nerka) from British Columbia, Canada. J Parasitol 83:1153-1156

Kent ML, Traxler GS, Kieser D, Richard J and others (1998) Survey of salmonid pathogens in ocean-caught fishes in British Columbia, Canada. J Aquat Anim Health 10: 211-219

Kent ML, Khattra J, Hedrick RP, Devlin RH (2000) Tetracapsula renicola n. sp. (Myxozoa: Saccosporidae): the PKX myxozoan - the cause of proliferative kidney disease of salmonid fishes. J Parasitol 86:103-111

Mahony A, Fraser S, Groman DB, Jones SRM (2015) Specific PCR for Myxobolus arcticus SSU rDNA in juvenile sockeye salmon Oncorhynchus nerka from British Columbia, Canada. Dis Aquat Org 115:87-92

* Margolis L, McDonald T, Whitaker D (1992) Assessment of the impact of the myxosporean parasite Ceratomyxa shasta on survival of seaward migrating juvenile chinook salmon, Oncorhynchus tshawytscha, from the Fraser River, British Columbia. Can J Fish Aquat Sci 49: 1883-1889
McDonald TE (1983) Ceratomyxa shasta Noble, 1950 (Myxozoa: Myxosporea) present in the Fraser River system of British Columbia. Can J Zool 61:1991-1994

* Meyers TR, Short S, Farrington C, Lipson K, Geiger HJ, Gates R (1993) Comparison of the enzyme-linked immunosorbent assay (ELISA) and the fluorescent antibody test (FAT) for measuring the prevalences and levels of Renibacterium salmoninarum in wild and hatchery stocks of salmonid fishes in Alaska, USA. Dis Aquat Org 16:181-189

Miller KM, Teffer A, Tucker S, Li S and others (2014) Infectious disease, shifting climates, and opportunistic predators: cumulative factors potentially impacting wild salmon declines. Evol Appl 7:812-855

Moles A, Heifetz J (1998) Effects of the brain parasite Myxobolus arcticus on sockeye salmon. J Fish Biol 52:146-151

Moles A, Jensen K (2000) Prevalence of the sockeye salmon brain parasite Myxobolus arcticus in selected Alaska streams. Alsk Fish Res Bull 6:85-93

Neville CM, Johnson SC, Beacham TD, Whitehouse T, Tadey J, Trudel M (2016) Initial estimates from an integrated study examining the residence period and migration timing of juvenile sockeye salmon from the Fraser River through coastal waters of British Columbia. North Pac Anadromous Fish Comm Bull 6:45-60

Palenzuela O, Trobridge G, Bartholomew JL (1999) Development of a polymerase chain reaction diagnostic assay for Ceratomyxa shasta, a myxosporean parasite of salmonid fish. Dis Aquat Org 36:45-51

* Preikshot D, Beamish RJ, Sweeting RM, Neville CM, Beacham TD (2012) The residence time of juvenile Fraser River sockeye salmon in the Strait of Georgia. Mar Coast Fish 4:438-449

* Quinn TP, Wood CC, Margolis L, Riddell BE, Hyatt KD (1987) Homing in wild sockeye salmon (Oncorhynchus nerka) populations as inferred from differences in parasite prevalence and allozyme allele frequencies. Can J Fish Aquat Sci 44:1963-1971

* Raverty S, Kieser D, Bagshaw J, St-Hilaire S (2000) Renal infestation with Parvicapsula minibicornis in wild sockeye salmon from the Harrison and Adams rivers in British Columbia. Can Vet J 41:317-318

* Sandell TA, Teel DJ, Fisher J, Beckman B, Jacobson KC (2015) Infections by Renibacterium salmoninarum and Nanophyetus salmincola Chapin are associated with reduced growth of juvenile Chinook salmon, Oncorhynchus tshawytscha (Walbaum), in the Northeast Pacific Ocean. J Fish Dis 38:365-378

Sanders J, Pilcher K, Fryer J (1978) Relation of water temperature to bacterial kidney disease in coho salmon (Oncorhynchus kisutch), sockeye salmon (O. nerka), and steelhead trout (Salmo gairdneri). J Fish Res Board Can 35:8-11

* Sanders JE, Long JJ, Arakawa CK, Bartholomew JL, Rohovec JS (1992) Prevalence of Renibacterium salmoninarum among downstream-migrating salmonids in the Columbia River. J Aquat Anim Health 4:72-75

St-Hilaire S, Boichuk M, Barnes D, Higgins M and others (2002) Epizootiology of Parvicapsula minibicornis in Fraser River sockeye salmon, Oncorhynchus nerka (Walbaum). J Fish Dis 25:107-120

Thomson RE, Beamish RJ, Beacham TD, Trudel M, Whitfield PH, Hourston RAS (2012) Anomalous ocean conditions may explain the recent extreme variability in Fraser River sockeye salmon production. Mar Coast Fish 4: 415-437 
Tucker S, Hipfner JM, Trudel M (2016) Size- and conditiondependent predation: a seabird disproportionately targets substandard individual juvenile salmon. Ecology 97: 461-471

Van Gaest AL, Dietrich JP, Thompson DE, Boylen DA and others (2011) Survey of pathogens in hatchery Chinook salmon with different out-migration histories through the Snake and Columbia Rivers. J Aquat Anim Health 23: 62-77

Wagner GN, Hinch SG, Kuchel LJ, Lotto A and others (2005)

Editorial responsibility: Dieter Steinhagen,

Hannover, Germany
Metabolic rates and swimming performance of adult Fraser River sockeye salmon (Oncorhynchus nerka) after a controlled infection with Parvicapsula minibicornis. Can J Fish Aquat Sci 62:2124-2133

Wickham H (2011) The split-apply-combine strategy for data analysis. J Stat Softw 40:29

K Zinn JL, Johnson KA, Sanders JE, Fryer JL (1977) Susceptibility of salmonid species and hatchery strains of Chinook salmon (Oncorhynchus tshawytscha) to infections by Ceratomyxa shasta. J Fish Res Board Can 34:933-936

Submitted: May 11, 2017; Accepted: July 18, 2017

Proofs received from author(s): September 16, 2017 